Article

\title{
Shift of Sediments Bacterial Community in the Black-Odor Urban River during In Situ Remediation by Comprehensive Measures
}

\author{
Jian Zhang ${ }^{1}$, Yun Tang ${ }^{1}$, Zhanguo Kou ${ }^{1}$, Xiao Teng ${ }^{2,3}$, Wei Cai ${ }^{1}$ and Jian Hu ${ }^{1, *}$ \\ 1 College of Environmental Science \& Engineering, Yangzhou University, Yangzhou 225100, China; \\ zhangj@yzu.edu.cn (J.Z.); ty18252785620@163.com (Y.T.); kzgleo2016@163.com (Z.K.); \\ caiwei@yzu.edu.cn (W.C.) \\ 2 Runsheng Environmental Technology (Guangzhou) Co., Ltd., Guangzhou 510006, China; \\ tengxiao7077@hotmail.com \\ 3 Huihong Environmental Technology (Jiangsu) Co., Ltd., Yangzhou 225100, China \\ * Correspondence: huj@yzu.edu.cn
}

Received: 31 August 2019; Accepted: 10 October 2019; Published: 14 October 2019

\begin{abstract}
The phenomenon of black-odor urban rivers with rapid urbanization has attracted extensive attention. In this study, we investigated the water quality and composition of sediment-associated bacteria communities in three remediation stages (before remediation, 30 days after remediation, and 90 days after remediation) based on the in situ remediation using comprehensive measures (physical, chemical, and biological measures). The results show that the overlying water quality was notably improved after in situ remediation, while the diversity and richness of sediment-associated bacterial communities decreased. A growing trend of some dominant genus was observed following the remediation of a black-odor river, such as Halomonas, Pseudomonas, Decarbonamis, Leptolina, Longilina, Caldiseericum, Smithella, Mesotoga, Truepera, and Ralstonia, which play an important role in the removal of nitrogen, organic pollutants and hydrogen sulfide $\left(\mathrm{H}_{2} \mathrm{~S}\right)$ during the sediment remediation. Redundancy analysis (RDA) showed that the bacterial community succession may accelerate the transformation of organic pollutants into inorganic salts in the sediment after in situ remediation. In a word, the water quality of the black-odor river was obviously improved after in situ remediation, and the bacterial community in the sediment notably changed, which determines the nutrients environment in the sediment.
\end{abstract}

Keywords: black-odor urban rivers; in situ remediation; water quality; sediment bacterial community

\section{Introduction}

Black-odor water is a body of water that emits an irritating and noxious smell, appears black or grayish black, and loses ecological function [1-3]. This phenomenon often occurs because a large amount of organic pollutants flowing into the water, accelerating the consumption of dissolved oxygen, and making the river anaerobic [2]. Under anaerobic conditions, organic pollutants can be degraded and converted into volatile gas compounds, such as $\mathrm{H}_{2} \mathrm{~S}$, organic sulfide, ammonia, amine and short-chain fatty acids, which are the main sources of odor in the river [3-5], and the degradation products will form blackening substances, such as ferrous sulfide and manganese sulfide, with ferrous and manganese in the sediment [6,7]. Urban rivers are an important part of the urban ecosystem, however, their blackening and odor production destroy the river ecosystem, damage the urban living environment, and severely restrict sustainable development of the city [8]. In recent years, the problem of black-odor urban rivers has become increasingly prominent with rapid urbanization [9]. In China, 
more than $4 / 5$ of the urban rivers are polluted and most of them have been turned into black-odor rivers [1]. It is urgent to remedy the black-odor urban rivers.

Dredging is the most direct and effective ex situ remediation technique to solve the problem of river blackening and odor production [10]. However, due to the difficulty of rapid treatment and secondary utilization of sediment, as well as the complexity of ex situ treatment projects [11], in situ remediation technologies, such as intermittent aeration, chemical injection, and microbiological measures, have been widely used to remedy the black-odor urban rivers in recent years. For instance, Uggetti et al., studied the treatment efficiency of intermittent aeration for pollutants in constructed wetlands, and found that intermittent aeration can significantly improve the removal rate of chemical oxygen demand (COD), ammonium and total nitrogen (TN) due to the coexistence of aerobic and anoxic conditions [12]. Nitrate dosing has been proved to be an economical and effective method to remove organic matter and odor caused by sulfur in the sediments by inhibiting anaerobic sulfate-reducing bacteria and stimulating nitrate-reducing bacteria and sulfate-oxidizing bacteria [13-15]. Similarly, calcium peroxide $\left(\mathrm{CaO}_{2}\right)$ can also effectively remove organic pollutants and reducible sulfur in water, because of calcium peroxide input can improve dissolved oxygen level and generate hydrogen peroxide and free radicals [16]. Different from physical (aeration) and chemical measures (input of nitrate and $\mathrm{CaO}_{2}$ ), biotechnology, as an environment-friendly treatment measure, is widely used in the remediation of the black-odor urban rivers [17]. Tu et al., carried out bioremediation of sediment by adding denitrifying bacteria, found that the addition of denitrifying bacteria had good effects on reducing sediment thickness, degrading organic matter and improving biodegradability [18]. Yao et al. studied the in situ reduction effect of immobilized microorganism technology on the bottom mud, and found that the thickness of sediment decreased by about $50 \%$, the color of the sediment changed from black to light brown, and the biochemical degradation ability of the sediment was enhanced [19]. Although the remediation of the black-odor urban river had gratifying achievements, these studies mainly focused on the removal rate of pollutants by a single remediation measure, and few studies have been conducted on the succession of microbial community structure in the process of remediation by integrated remediation measures. The comprehensive use of physics, chemistry and biotechnology not only provides good living conditions for aquatic microorganisms, but also stimulates or strengthens the microbial biodegradability of pollutants during black-odor river remediation. Therefore, understanding the shift in the microbial community during black-odor river remediation is of great significance to guide the treatment and later management of black-odor rivers.

Sediment is an ecological environment that integrates various pollutants and microorganisms, which continuously exchanging material and energy with the overlying water, and has multiple functions such as dilution, adsorption and biological degradation, playing an irreplaceable role in the self-purification of rivers $[20,21]$. However, a large amount of organic pollutants accumulate in the sediment weakens the self-purification ability, resulting in the blackening and stinking of the river $[7,22]$. Microorganisms, as the main driving force of geochemical cycle, play an important role in organic matter decomposition and nutrient mineralization in aquatic ecosystems [23]. At present, there have been reports on the composition of bacterial communities in urban rivers. For example, Zhang et al. analyzed the bacterial community composition and its driving factors in heavily polluted rivers from both vertical and horizontal perspectives by Illumina MiSeq sequencing [24]. Cai et al. analyzed the composition of bacteria community in the sediment of the black-odor river and its effect on the transformation of sulfur in water using Illumina MiSeq sequencing and GeoChip techniques [2]. Although these studies have analyzed the spatial distribution of bacterial communities in the black-odor rivers, there is little research on the sediment-associated bacterial community succession during the remediation of black-odor rivers.

Based on comprehensive measures, the physicochemical properties of overlying water and sediment, as well as the composition of the bacteria community in the sediment, were investigated in the three in situ remediation stages. The aim was to clarify the succession of bacterial community structure during the in situ remediation process; explore the relationship between the bacterial 
community composition and physicochemical characteristics; and provide important support for improving water quality and eliminating black odor.

\section{Materials and Methods}

\subsection{Sites and In Situ Remediation Description}

Double Bridge River (DBR) is a black-odor urban river, located in Yangzhou, Jiangsu Province, East China, an urban river with total length of $2700 \mathrm{~m}$ and width of about $12 \mathrm{~m}$. Representative river sections (about $1100 \mathrm{~m}$ ) were selected for in situ remediation, with both ends blocked and cut off to reduce water exchange. In situ remediation of black-odor rivers adopts integrated remediation technology. Simply put, this technology includes, (1) physical measures: mechanical sediment loosening, intermittent aeration and add zeolite to provide a good carrier surface for the microorganisms; (2) chemical measures: $\mathrm{CaO}_{2}$ and calcium nitrate addition to remove toxic and harmful pollutants and create a suitable growth and living environment for microorganisms; (3) biology measures: addition of microbial growth promoters to provide nutrients to microorganisms.

\subsection{Sample Collection}

Samples of overlying water and sediment were collected at three stages, namely before remediation (DBR1), 30 days after remediation (DBR2), and 90 days after remediation (DBR3). For each stage, three sampling sites, with intervals of 250-300 m, were set up along the river. Overlying water was collected under the surface of river $(0.5 \mathrm{~m})$ and sediment was collected from the depth of $0-20 \mathrm{~cm}$ below the river bottom. The sample was transferred to sterile container and immediately returned to the laboratory. Subsequently, overlying water samples are immediately measured, and sediment samples were stored at $-80{ }^{\circ} \mathrm{C}$ until physicochemical tests and DNA extraction.

\subsection{Analysis of Physicochemical Parameters}

Physicochemical parameters of overlying water, including ammonium, TN, total phosphorus (TP), and COD, were determined according to the method described by the State Environmental Protection Administration of China [25]. Briefly, ammonium was determined by Nessler's reagent spectrophotometric method; TN was detected by UV spectrophotometric method; TP was detected by the ammonium molybdate spectrophotometric method; COD was detected by the potassium permanganate oxidation method. In addition, available $\mathrm{P}, \mathrm{TP}$, ammonium, $\mathrm{TN}$, nitrate, organic matter $(\mathrm{OM})$, and sulfate of sediments were also determined using standard methods, as described by Lu [26]. Available P and TP was determined by Mo-Sb anti spectrophotometric method; ammonium was determined by indophenol blue colorimetry; TN was determined by Kjeldahl method; nitrate was determined by UV spectrophotometric method; OM was detected by high temperature external thermal potassium dichromate oxidation-volumetric method; sulfate was determined by barium sulfate turbidimetry. Samples were analyzed in triplicate.

\subsection{DNA Extraction and Illumina Miseq Sequencing}

DNA was extracted from $0.5 \mathrm{~g}$ of sediment using the Power-Soil ${ }^{\mathrm{TM}}$ DNA Isolation Kit (MO BIO Laboratories Inc., Carlsbad, CA, USA) according to the manufacturer's instructions. DNA extracts were stored at $-20^{\circ} \mathrm{C}$. Bacterial communities were measured by the Illumina Miseq System by Personal Biotechnology Co., Ltd. (Shanghai, China). The 16S rRNA genes were amplified using the following universal primer set: 515f (5'-GTGCCAGCMGCCGCGGTAA-3') and 907r ( $5^{\prime}$-CCGTCAATTCMTTTRAGTTT-3') primer set fused with an index sequenece. A $25 \mu \mathrm{L}$ reaction mixture contained $5 \mu \mathrm{L} 5 \times$ reaction buffer, $5 \mu \mathrm{L} 5 \times$ GC buffer, $2 \mu \mathrm{L}$ dNTP $(2.5 \mathrm{mM}), 1 \mu \mathrm{L}$ of each primer $(10 \mu \mathrm{M}), 10 \mathrm{ng}$ template DNA, $0.25 \mu \mathrm{L}$ Q $5^{\circledR}$ High-Fidelity DNA Polymerase (NEB), and $\mathrm{ddH}_{2} \mathrm{O}$ was supplemented to $25 \mu \mathrm{L}$. The temperature cycle consisted of $98^{\circ} \mathrm{C}$ for $1 \mathrm{~min}$, followed by 30 cycles 
of $98^{\circ} \mathrm{C}$ for $15 \mathrm{~s}, 55^{\circ} \mathrm{C}$ for $30 \mathrm{~s}, 72{ }^{\circ} \mathrm{C}$ for $30 \mathrm{~s}$, and a final extension at $72{ }^{\circ} \mathrm{C}$ for $10 \mathrm{~min}$. Samples were analyzed in triplicate.

\subsection{Bioinformatics Analysis}

The raw data sequence obtained from Illumina MiSeq sequencing were analyzed using the QIIME software (version 1.8.0, http://qiime.org/) [27]. Firstly, we deleted the low quality or ambiguous sequencing reads (reads with lengths $<150 \mathrm{bp}$, ambiguous bases $\mathrm{N}, 5^{\prime}$ prime mismatch, $>8$ contiguous same bases, or average base accuracy <99\%). Subsequently, the USEARCH tool (v5.2.236, http: //www.drive5.com/usearch/) was used to check and eliminate chimeric sequences. The high-quality sequences were clustered into Optical Transform Units (OTUs) at 97\% distance sequence similarity. To ensure the reliability and accuracy of the results, OTUs with an abundance $<0.001 \%$ of the total number of sequences were removed [28]. Subsequently, the sequence with the highest abundance per OTU, which is selected as the representative sequence of the OTU, was compared to the sequences in the Silva database (Release115, http://www.arb-silva.de) to obtain taxonomic information corresponding to each OTU. The rarefaction curves of Shannon, Chao1 and observed species were calculated using QIIME.

\subsection{Statistical Analyses}

Collected data were subjected to analysis of variance (ANOVA) using SPSS 18.0 (Chicago, IL, USA). Differences between stages were tested via analysis of variance with Duncan's multiple range test. The significance level was set to $p<0.05$. RDA was performed to analyze the relationship between physicochemical parameters and bacteria community, dominant genera in the sediment using the statistical program Canoco for Windows (version 4.5, Wageningen, The Netherlands).

\section{Results}

\subsection{Physicochemical Parameters of the Overlying Water and Sediment among Different Restoration Stages}

During the early stages of restoration from DBR1 to DBR2, all parameters in the water were significantly reduced, such as ammonium decreased from $2.5 \mathrm{mg} / \mathrm{L}$ to $1.2 \mathrm{mg} / \mathrm{L}$, TN decreased from $19.5 \mathrm{mg} / \mathrm{L}$ to $2.1 \mathrm{mg} / \mathrm{L}$, TP decreased from $11.3 \mathrm{mg} / \mathrm{L}$ to $0.3 \mathrm{mg} / \mathrm{L}$, and COD decreased from 173.7 $\mathrm{mg} / \mathrm{L}$ to $24.1 \mathrm{mg} / \mathrm{L}$ (Figure 1). In addition, ammonium in the water increased significantly from DBR2 to DBR3, but it was still lower than the content of ammonium in water before remediation. The physicochemical properties of the sediment also changed significantly with the remediation of black-odor water. Available P, TP, ammonium, TN, nitrate, OM, and sulfate in DBR1 were significantly lower than DBR2 and DBR3, of which TP, nitrate, TN, OM and sulfate significantly decreased from DBR2 to DBR3.

\subsection{Rarefaction Curves of Bacteria among Different Restoration Stages}

The rarefaction curves of Chao1 estimator, Shannon index and observed species were used to estimate and compare bacterial diversity and richness among different restoration stages (Figure 2). All rarefaction curves tended to be smooth, indicating that the diversity and richness of sequences derived in this study were sufficient to characterize bacterial species in each sample. Black-odor river remediation reduced the Shannon index, Chao1 estimator and observed species. Specifically, the Shannon index of DBR2 and DBR3 decreased from 9.6 in DBR1 to 6.8 and 6.0, respectively. Correspondingly, the Chao1 index decreased from 1996 to 1281 and 1071, respectively; the observed species decreased from 1768 to 1040 and 883, respectively. 

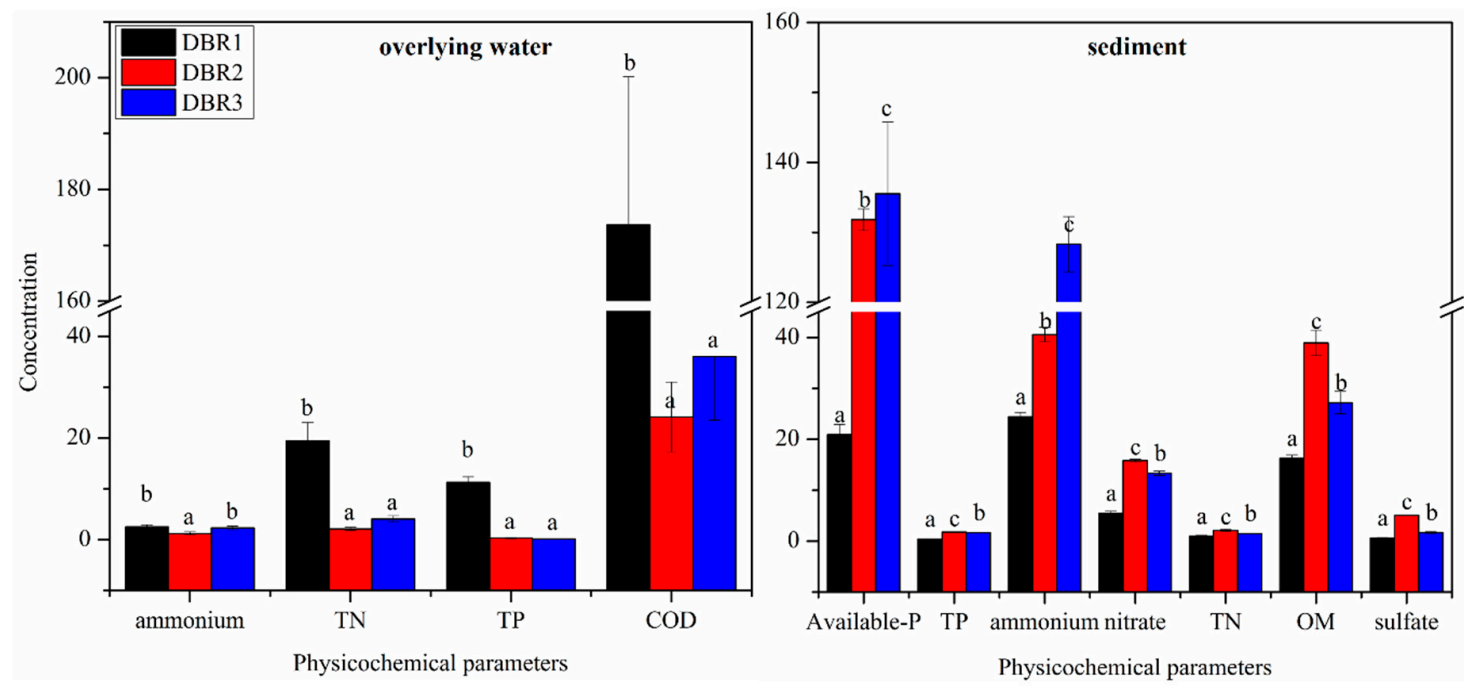

Figure 1. Physicochemical parameters of the overlying water and sediment in different remediation stages. (the overlying water parameter unit: $\mathrm{mg} / \mathrm{L}$; in the sediment, unit of available $\mathrm{P}$, ammonium, nitrate: $\mathrm{mg} / \mathrm{kg}$; unit of TP (total phosphorus), TN (total nitrogen), OM (organic matter), sulfate: $\mathrm{g} / \mathrm{kg}$; $\mathbf{a}, \mathbf{b}$, and $\mathbf{c}$ indicate significant differences $(p<0.05)$ within different treatments based on Duncan's multiple range test.).
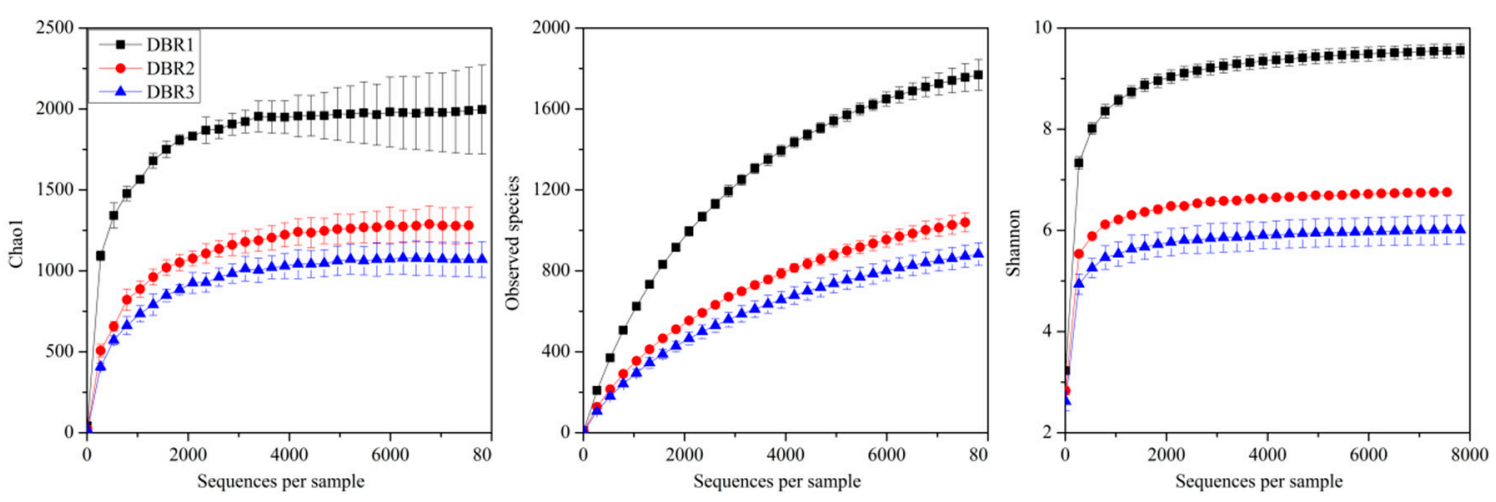

Figure 2. Rarefaction curves of Chao1, observed species, and Shannon of sediments in different remediation stages.

\subsection{Microbial Community Composition among Different Restoration Stages}

Among the 44 phyla detected in all samples, the most predominate was Proteobacteria, accounting for 47.7 to $77.7 \%$ of the total sequences (Figure 3). Chloroflexi, Acidobacteria, and Actinobacteria were the subdominant groups, which occupied $7.9-19.2 \%, 1.0-8.8 \%$, and $1.8-8.3 \%$ of the assigned sequences, respectively. These four dominant phyla accounted for more than $83.2 \%$ of the total classified sequences. Proteobacteria, which consists mainly of 4 classes, such as Gammaproteobacteria (27.1-70.2\%), Alphaproteobacteria (0.9-9.1\%), Betaproteobacteria (2.1-6.8\%), and Deltaproteobacteria (3.6-4.7\%), its proportion in the bacterial community increased significantly with the remediation of the black-odor river, but the reverse is true for Chloroflexi (predominate Anaerolineae), Acidobacteria, and Actinobacteria. 


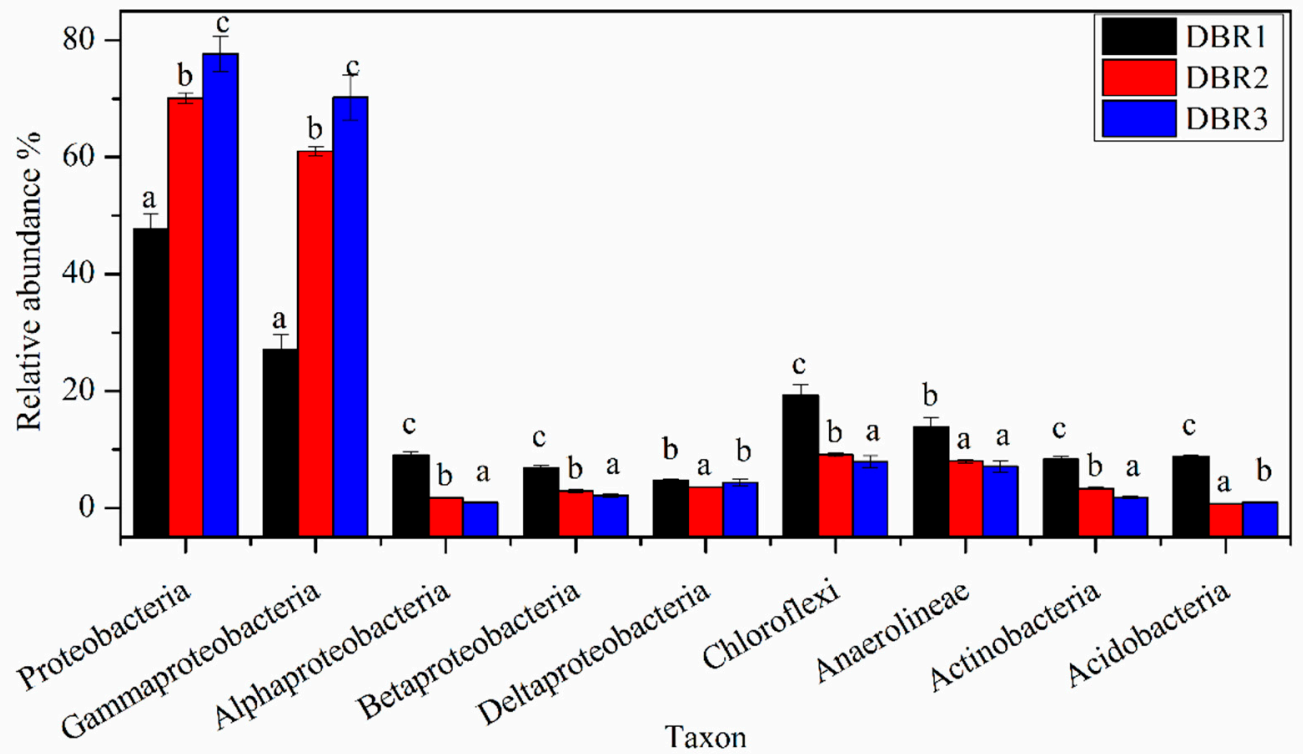

Figure 3. Relative abundance dominant taxon in different remediation stages. $(\mathbf{a}, \mathbf{b}$, and $\mathbf{c}$ indicate significant differences $(p<0.05)$ within different treatments based on Duncan's multiple range test.).

A total of 501 genera were observed in all samples. Halomonas and Pseudomonas, the two most dominant genera in each stage, increased obviously with the treatment of black odor (Figure 4). The relative abundance of Anaerolinea, Nocardioides, Variibacter, Bryobacter, Thiobacillus, Acidibacter, Gaiella, Roseiflexus, Geobacter, Nitrobacter, Pseudolabrys, Bacillus, and Solirubrobacter gradually decreased from DBR1 to DBR3 with the remediation of black odor, while the relative abundance of Leptolinea and Longilinea increased as the restoration progressed. The genera Dechloromonas, Ralstonia, Smithella, Truepera, Mesotoga, and Caldisericum showed relatively low relative abundances in DBR1, but obviously increased in DBR2 and DBR3. In addition, Flavobacterium and Sulfuricurvum showed relatively high relative abundance in DBR2, but showed no significant differences in DBR1 and DBR3.

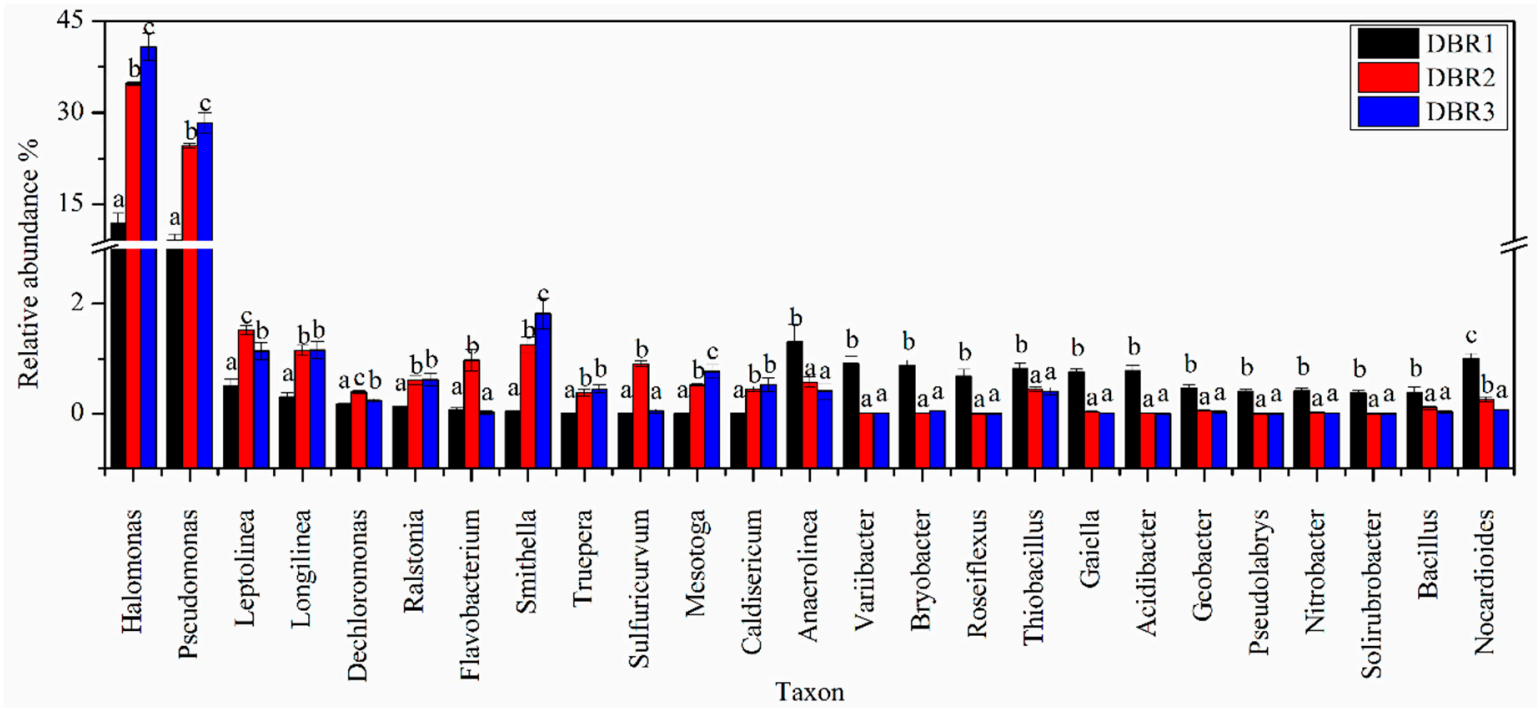

Figure 4. Relative abundance dominant genus of sediment in different remediation stages. $(\mathbf{a}, \mathbf{b}$, and c indicate significant differences $(p<0.05)$ within different treatments based on Duncan's multiple range test.). 


\section{Discussion}

The results show that ammonium, $\mathrm{TN}, \mathrm{TP}$, and COD of the overlying water decrease to different degrees during the in situ remediation (Figure 1), indicating that the in situ remediation significantly improved the water quality of the black-odor river, which is consistent with previous studies $[10,13,16]$. However, nutrients, TN, TP and OM in the sediment showed an increasing trend (Figure 1). The reason for this phenomenon is that the oxidation reduction potential, carbon sources and growth factors of microorganisms increased in the sediment due to the in situ remediation, thus improving the activity of microorganisms and promoting the decomposition of organic pollutants in the sediment. In addition, we also found that TN and TP in the sediment were negatively correlated with those in the overlying water, which is disagree with Zhang et al. study [24]. The reason for this difference may be that the addition of zeolite, $\mathrm{CaO}_{2}$ and calcium nitrate inhibited the release of $\mathrm{N}$ and $\mathrm{P}$ in the sediment during the remediation.

Microorganisms are the main driving force of pollutant degradation in the sediment, and vary with the environment [23,29]. Therefore, it is necessary to study the composition succession of sediment-associated bacterial communities during the remediation of urban black-odor rivers. Previous study demonstrated that the diversity of bacteria in the sediment exhibited a downward trend with the improvement of urban rivers [5]. This result was also confirmed in this study, which showed that the diversity and richness of sediment-associated bacterial decreased significantly after in situ remediation of the black-odor river (Figure 2). This may be because the dissolved oxygen in the sediment increased after in situ remediation, resulting in an increase of facultative and aerobic microorganisms and a decrease in obligate anaerobic microbes. For example, the relative abundance of Halomonas and Pseudomonas increased continuously, and reaching $69.0 \%$, while the relative abundance of Anaerolineae decreased from $13.9 \%$ to $7.1 \%$ (Figure 4). Moreover, it is worth noting that the decrease of microbial diversity also weakens the stability of river ecosystem and the buffering capacity against the deterioration of microecology [30]. RDA showed that the sediment-associated bacterial community underwent significant changes during in situ remediation, and significant correlation with nutrients, TN, TP, and OM (Figure 5A), which may be because the remediation stimulates the reproduction of some microorganisms and enhanced the biochemical process in the sediment, thus increasing nutrients, $\mathrm{TN}, \mathrm{TP}, \mathrm{OM}$. In other words, the composition of microbial communities determines the chemical properties of the sediment.

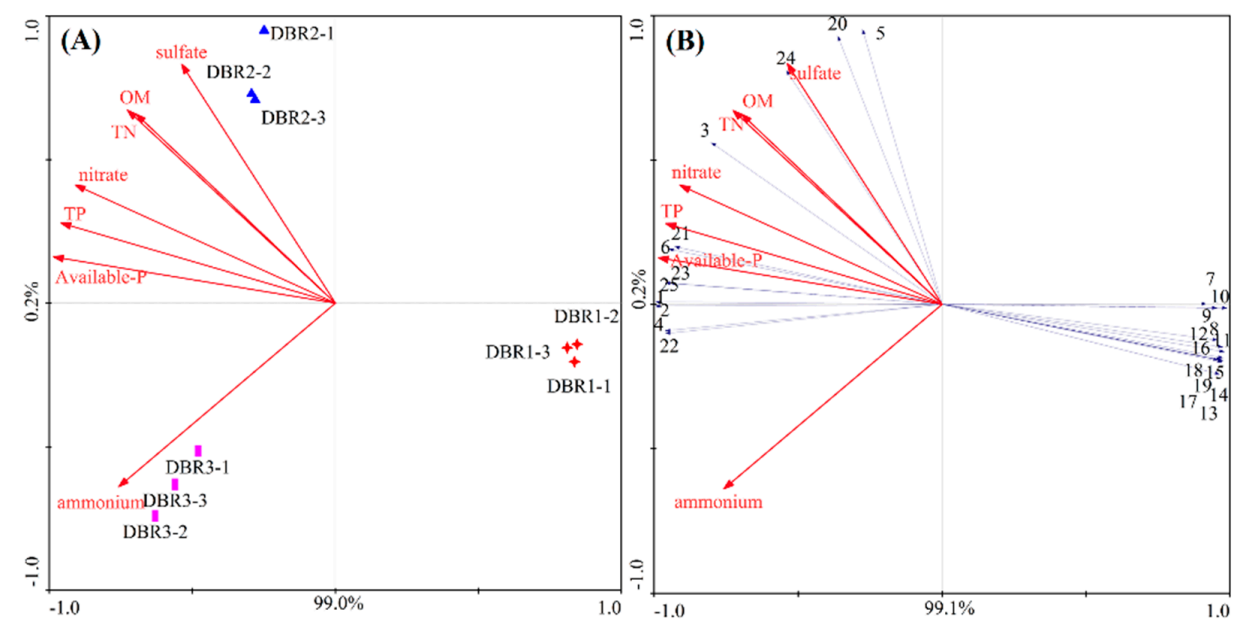

Figure 5. Redundancy analysis (RDA) of bacterial community (A), dominant genus (B), and soil properties. (Genera corresponding to the numbers in Figure 5B are shown as follows. 1. Halomonas, 2. Pseudomonas, 3. Leptolinea, 4. Smithella, 5. Flavobacterium, 6. Longilinea, 7. Anaerolinea, 8. Thiobacillus, 9. Nocardioides, 10. Bacillus, 11. Gaiella, 12. Geobacter, 13. Variibacter, 14. Bryobacter, 15. Roseiflexus, 16. Acidibacter, 17. Pseudolabrys, 18. Nitrobacter, 19. Solirubrobacter, 20. Sulfuricurvum, 21. Ralstonia, 22. Mesotoga, 23. Caldisericum, 24. Dechloromonas, 25. Truepera.). 
Proteobacteria, Chloroflexi, Acidobacteria, and Actinobacteria were the dominant phyla of the sediment-associated bacteria community in the black-odor river (Figure 3), which has also been confirmed in previous study [1]. In addition, the results also showed that the relative abundance of Proteobacteria increased significantly with the remediation of the black-odor river, especially Gammaproteobacteria. Gammaproteobacteria plays an important role in the circulation of C, N, S in aquatic environment [31,32]. Chloroflexi show a high relative abundance in low oxygen environment [33], while the proportion of Chloroflexi dominated by Anaerolineae class in bacterial community gradually decreased, indicating that dissolved oxygen in black-odor rivers increased with the remediation of sediment. Additionally, sediment remediation increases the nutrient content, which may be responsible for the relative abundance of Acidobacteria and Actinobacteria decreases [34,35].

Among the top 25 genera in abundance, Halomonas play a role in nitrogen removal and hydrocarbon degradation [36,37], Decarbonamis and Pseudomonas are considered denitrifying bacteria [37,38]. Leptolinea, Longilinea and Caldisericum can perform anaerobic fermentation [39,40], Smithella and Mesotoga can degrade the fermentation products of organic matters [41], Truepera has the ability to degrade phenanthrene [42], Ralstonia plays an important role in the degradation of cellulose and hemicellulose [43]. The relative abundance of these organism increases following the river remediation, and is positively correlated with the content of nutrient of the sediment (Figures 4 and 5B). This shows that the remediation of the black-odor river provides a good living environment for these denitrifying bacteria and hydrocarbon degrading bacteria. In turn, these organisms play an important role in removing $\mathrm{N}, \mathrm{H}_{2} \mathrm{~S}$ and organic matter in the sediment remediation process [15]. It is worth noting that the increase of organic pollution-degrading bacteria leads to an increase in the availability of nutrients in the sediments, and the weakening of the bacterial ecosystem to the external environment, which increases the risk of aquatic eutrophication [44]. Therefore, it is necessary to pay attention to the fixation and removal of $\mathrm{N}, \mathrm{P}$ in the sediment in the later river maintenance.

\section{Conclusions}

After in situ remediation, the water quality of the black-odor river was improved, and the composition and function of sediment-associated bacterial communities changed significantly. Specifically, the contents of DOC, TP, TN and ammonium in the overlying water decreased significantly after restoration; as did the diversity and richness of sediment bacteria decreased. Among the dominant phyla, the relative abundance of Proteobacteria increased significantly, and reaching 77.7\%, while the reverse is true for Chloroflexi, Acidobacteria, and Actinobacteria. The dominant genera, Halomonas, Pseudomonas, Decarbonamis, Leptolinea, Longilinea, Caldisericum, Smithella, Mesotoga, Truepera, and Ralstonia gradually increased during in situ remediation, playing an important role in the removal of $\mathrm{N}, \mathrm{H}_{2} \mathrm{~S}$ and organic matter in the sediment. In addition, RDA showed that the bacterial community in the sediment dominated the formation of nutrient environments.

Author Contributions: J.Z. and W.C. participated in the design of the study; Y.T. and Z.K.; carried out the experiment; X.T. was responsible for the remediation; J.H. participated in the design of the study and edited the manuscript. All authors read and approved the final manuscript.

Funding: This work was supported by the National Natural Science Foundation of China $(41977053,51909229)$.

Conflicts of Interest: The authors declare no conflict of interest.

\section{References}

1. Ji, X.; Zhang, W.; Jiang, M.; He, J.; Zheng, Z. Black-odor water analysis and heavy metal distribution of Yitong River in Northeast China. Water Sci. Technol. 2017, 76, 2051-2064. [CrossRef] [PubMed]

2. Cai, W.; Li, Y.; Shen, Y.; Wang, C.; Wang, P.F.; Wang, L.F.; Niu, L.; Zhang, W. Vertical distribution and assemblages of microbial communities and their potential effects on sulfur metabolism in a black-odor urban river. J. Environ. Manag. 2019, 235, 368-376. [CrossRef] [PubMed] 
3. Bentley, R.; Chasteen, T.G. Environmental VOSCs-formation and degradation of dimethyl sulfide, methanethiol and related materials. Chemosphere 2004, 55, 291-317. [CrossRef] [PubMed]

4. Ginzburg, B.; Dor, I.; Chalifa, I.; Hadas, O.; Lev, O. Formation of dimethyloligosulfides in Lake Kinneret: Biogenic formation of inorganic oligosulfide intermediates under oxic conditions. Environ. Sci. Technol. 1999, 33, 571-579. [CrossRef]

5. Wu, Y.F.; Lin, H.; Yin, W.Z.; Shao, S.C.; Lv, S.H.; Hu, Y.Y. Water Quality and Microbial Community Changes in an Urban River after Micro-Nano Bubble Technology In Situ Treatment. Water 2019, 11, 66. [CrossRef]

6. Metzger, E.; Langlet, D.; Viollier, E.; Koron, N.; Riedel, B.; Stachowitsch, M.; Faganeli, J.; Tharaud, M.; Geslin, E.; Jorissen, F. Artificially induced migration of redox layers in a coastal sediment from the Northern Adriatic. Biogeosciences 2014, 11, 2211-2224. [CrossRef]

7. Liang, Z.; Siegert, M.; Fang, W.; Sun, Y.; Jiang, F.; Lu, H.; Chen, G.-H.; Wang, S. Blackening and odorization of urban rivers: A bio-geochemical process. FEMS Microbiol. Ecol. 2018, 94. [CrossRef]

8. Burns, E.E.; Carter, L.J.; Kolpin, D.W.; Thomas-Oates, J.; Aba, B. Temporal and spatial variation in pharmaceutical concentrations in an urban river system. Water Res. 2018, 137, 72-85. [CrossRef]

9. Wang, X.J.; Zhang, F.H.; Wu, Z.; Yang, L.Z.; Yin, D.Q.; Cheng, S.P. Experimental Study on Combined Bio-carrier for Pretreatment of Black Odor River Water. China Water Wastewater 2012, 28, 71-73.

10. Chattopadhyay, S.; Chattopadhyay, D. Remediation of DDT and Its Metabolites in Contaminated Sediment. Curr. Pollut. Rep. 2015, 1, 248-264. [CrossRef]

11. Li, W.P.; Zhang, S.K.; Zhang, L.Y.; Li, X.G.; Wang, F.; Li, G.W.; Li, J.X.; Li, W. In-situ remediation of sediment by calcium nitrate combined with composite microorganisms under low-DO regulation. Sci. Total Environ. 2019, 697. [CrossRef] [PubMed]

12. Uggetti, E.; Hughes-Riley, T.; Morris, R.H.; Newton, M.L.; Trabi, C.L.; Hawes, P.; Puigagut, J.; García, J. Intermittent aeration to improve wastewater treatment efficiency in pilot-scale constructed wetland. Sci. Total Environ. 2016, 559, 212-217. [CrossRef] [PubMed]

13. Zhang, M.; Zhang, T.; Shao, M.F.; Fang, H. Autotrophic denitrification in nitrate-induced marine sediment remediation and Sulfurimonas denitrificans-like bacteria. Chemosphere 2009, 76, 677-682. [CrossRef] [PubMed]

14. Perelo, L.W. Review: In situ and bioremediation of organic pollutants in aquatic sediments. J. Hazard. Mater. 2010, 177, 81-89. [CrossRef] [PubMed]

15. Chen, L.; Wang, L.Y.; Liu, S.J.; Hu, J.Y.; He, Y.; Zhou, H.W.; Zhang, X.H. Profiling of microbial community during in situ remediation of volatile sulfide compounds in river sediment with nitrate by high throughput sequencing. Int. Biodeter. Biodegr. 2013, 85, 429-437. [CrossRef]

16. Lu, S.G.; Zhang, X.; Xue, Y.F. Application of calcium peroxide in water and soil treatment: A review. J. Hazard. Mater. 2017, 337, 163-177. [CrossRef] [PubMed]

17. Gao, H.; Xie, Y.B.; Hashim, S.; Khan, A.A.; Wang, X.L.; Xu, H.Y. Application of Microbial Technology Used in Bioremediation of Urban Polluted River: A Case Study of Chengnan River, China. Water 2018, 10, 643. [CrossRef]

18. Tu, W.L.; Hu, Z.B.; Liang, Y.C.; Lu, H.; Liu, K.H.; Jiang, Z. Experimental study on remediation of sediments in urban black-odorous rivers by denitrifying bacteria. Environ. Eng. 2015, 33, 5-9.

19. Yao, C.L.; Xu, Z.Q.; Yang, J.; Liu, R.R.; Zhou, A.C. Pilot-scale Study on In-situ Reduction of Black and Odorous Sediment in River Channel by Immobilized Microorganism Technology. J. Irrig. Drain. 2018, 37, 122-127.

20. Wobus, A.; Bleul, C.; Maassen, S.; Scheerer, C.; Schuppler, M.; Jacobs, E.; Röske, I. Microbial diversity and functional characterization of sediments from reservoirs of different trophic state. FEMS Microbiol. Ecol. 2003, 46, 331-347. [CrossRef]

21. Zhao, Y.K.; Bai, Y.; Guo, Q.; Li, Z.L.; Qi, M.Y.; Ma, X.D.; Wang, H.; Kong, D.Y.; Wang, A.J.; Liang, B. Bioremediation of contaminated urban river sediment with methanol stimulation: Metabolic processes accompanied with microbial community changes. Sci. Total Environ. 2019, 653, 649-657. [CrossRef] [PubMed]

22. He, D.F.; Chen, R.R.; Zhu, E.H.; Chen, N.; Yang, B.; Shi, H.H. Toxicity bioassays for water from black-odor rivers in Wenzhou, China. Environ. Sci. Pollut. Res. Int. 2015, 22, 1731-1741.

23. Chen, Y.; Liu, Y.; Li, Y.; Wu, Y.; Chen, Y.; Zeng, G.; Zhang, J.; Li, H. Influence of biochar on heavy metals and microbial community during composting of river sediment with agricultural wastes. Bioresour. Technol. 2017, 243, 347-355. [CrossRef] [PubMed] 
24. Zhang, W.L.; Lei, M.T.; Li, Y.; Wang, P.F.; Wang, C.; Gao, Y.; Wu, H.N.; Xu, C.; Niu, L.H.; Wang, L.F.; et al. Determination of vertical and horizontal assemblage drivers of bacterial community in a heavily polluted urban river. Water Res. 2019, 161, 98-107. [CrossRef]

25. State Environmental Protection Administration of China. Monitor and Analysis Method of Water and Wastewater, 4th ed.; Chinese Environmental Science Publication House: Beijing, China, 2002.

26. Lu, R.K. Analytical Methods of Soil Agrochemistry; China Agricultural Science and Technology Press: Beijing, China, 2000; pp. 146-195.

27. Caporaso, J.G.; Kuczynski, J.; Stombaugh, J.; Bittinger, K.; Bushman, F.D.; Costello, E.K.; Fierer, N.; Peña, A.G.; Goodrich, J.K.; Gordon, J.I.; et al. QIIME allows analysis of high-throughput community sequencing data. Nat. Methods 2010, 7, 335-336. [CrossRef]

28. Bokulich, N.A.; Subramanian, S.; Faith, J.J.; Gevers, D.; Gordon, J.I.; Knight, R.; Mills, D.A.; Caporaso, J.G. Quality-filtering vastly improves diversity estimates from Illumina amplicon sequencing. Nat. Methods 2013, 10, 57-59. [CrossRef]

29. Cardoso, S.J.; Nabout, J.C.; Farjalla, V.F.; Lopes, P.M.; Bozelli, R.L.; Huszar, V.L.M.; Roland, F. Environmental factors driving phytoplankton taxonomic and functional diversity in Amazonian floodplain lakes. Hydrobiologia 2017, 802, 115-130. [CrossRef]

30. Janvier, C.; Villeneuve, F.; Alabouvette, C.; Edel-Hermann, V.; Mateille, T.; Steinberg, C. Soil health through soil disease suppression: Which strategy from descriptors to indicators? Soil Biol. Biochem. 2007, 39, 1-23. [CrossRef]

31. Wang, Y.; Sheng, H.F.; He, Y.; Wu, J.Y.; Jiang, Y.X.; Tam, N.F.Y.; Zhou, H.W. Comparison of the Levels of Bacterial Diversity in Freshwater, Intertidal Wetland, and Marine Sediments by Using Millions of Illumina Tags. Appl. Environ. Microbiol. 2012, 78, 8264-8271. [CrossRef]

32. Kuypers, M.M.M.; Marchant, H.K.; Kartal, B. The microbial nitrogen-cycling network. Nat. Rev. Microbiol. 2018, 16, 263-276. [CrossRef]

33. Grégoire, P.; Fardeau, M.L.; Joseph, M.; Guasco, S.; Hamaide, F.; Biasutti, S.; Michotey, V.; Bonin, P.; Ollivier, B. Isolation and characterization of Thermanaerothrix daxensis gen. nov.; sp. nov.; a thermophilic anaerobic bacterium pertaining to the phylum "Chloroflexi", isolated from a deep hot aquifer in the Aquitaine Basin. Syst. Appl. Microbial. 2011, 34, 494-497. [CrossRef] [PubMed]

34. Zwart, G.; Crump, B.; Agterveld, M.P.K.V.; Hagen, F.; Han, S.K. Typical freshwater bacteria: An analysis of available $16 \mathrm{~S}$ rRNA gene sequences from plankton of lakes and rivers. Aquat. Microb. Ecol. 2002, 28, 141-155. [CrossRef]

35. Fierer, N.; Bradford, M.A.; Jackson, R.B. Toward an ecological classification of soil bacteria. Ecology 2007, 88, 1354-1364. [CrossRef] [PubMed]

36. García, M.T.; Encarnación, M.; Ostos, J.C.; Ventosa, A. Halomonas organivorans sp nov.; a moderate halophile able to degrade aromatic compounds. Int. J. Syst. Evol. Microbiol. 2004, 54, 1723-1728. [CrossRef]

37. Wan, Y.; Ruan, X.H.; Wang, J.; Shi, X. Spatial and seasonal variations in the abundance of nitrogen-transforming genes and the microbial community structure in freshwater lakes with different trophic satuses. Int. J. Environ. Res. Public Health 2019, 16, 2298. [CrossRef]

38. Huang, J.; Cao, C.; Yan, C.; Guan, W.; Liu, J. Comparison of Iris pseudacorus wetland systems with unplanted systems on pollutant removal and microbial community under nanosilver exposure. Sci. Total Environ. 2018, 624, 1336-1347. [CrossRef]

39. Zhang, Y.; Li, Q.; Chen, Y.; Dai, Q.G.; Hu, J. Dynamic Change in Enzyme Activity and Bacterial Community with long-term rice Cultivation in Mudflats. Curr. Microbiol. 2019, 76, 361-369. [CrossRef]

40. Shi, J.X.; Han, Y.X.; Xu, C.Y.; Han, H.J. Enhanced biodegradation of coal gasification wastewater with anaerobic biofilm on polyurethane (PU), powdered activated carbon (PAC), and biochar. Bioresour. Technol. 2019, 289, 121487. [CrossRef]

41. Liu, Y.; Gu, M.Q.; Yin, Q.D.; Wu, G.X. Inhibition mitigation and ecological mechanism of mesophilic methanogenesis triggered by supplement of ferroferric oxide in sulfate-containing systems. Bioresour. Technol. 2019, 288, 121546. [CrossRef]

42. Wang, F.K.; Li, C.; Wang, H.J.; Chen, W.L.; Huang, Q.Y. Characterization of a phenanthrene-degrading microbial consortium enriched from petrochemical contaminated environment. Int. Biodeter. Biodegr. 2016, 115, 286-292. [CrossRef] 
43. Lee, L.S.; Goh, K.M.; Chan, C.S.; Annie Tan, G.Y.; Yin, W.F.; Chong, C.S.; Chan, K.G. Microbial diversity of thermophiles with biomass deconstruction potential in a foliage-rich hot spring. Microbiologyopen 2018, 7 , e00615. [CrossRef] [PubMed]

44. Pan, M.; Zhao, J.; Zhen, S.; Heng, S.; Wu, J. Effects of the combination of aeration and biofilm technology on transformation of nitrogen in black-odor river. Water Sci. Technol. 2016, 74, 655-662. [CrossRef] [PubMed]

(C) 2019 by the authors. Licensee MDPI, Basel, Switzerland. This article is an open access article distributed under the terms and conditions of the Creative Commons Attribution (CC BY) license (http://creativecommons.org/licenses/by/4.0/). 